\title{
How High Is the Recreation Value of Successional Forests Growing Spontaneously on Coal Mine Spoil Heaps?
}

\author{
Markéta Braun Kohlová (D), Vojtěch Máca (D), Jan Melichar* and Petr Pavelčík \\ Environment Centre, Charles University, 16200 Prague, Czech Republic; \\ marketa.braun.kohlova@czp.cuni.cz (M.B.K.); vojtech.maca@czp.cuni.cz (V.M.); petr.pavelcik@czp.cuni.cz (P.P.) \\ * Correspondence: jan.melichar@czp.cuni.cz; Tel.: +420-220-199-464
}

Citation: Braun Kohlová, M.; Máca, V.; Melichar, J.; Pavelč́́k, P. How High Is the Recreation Value of Successional Forests Growing Spontaneously on Coal Mine Spoil Heaps?Forests 2021, 12, 160. https://doi.org/10.3390/f12020160

Academic Editor: Alessandro Paletto Received: 8 December 2020

Accepted: 26 January 2021

Published: 29 January 2021

Publisher's Note: MDPI stays neutral with regard to jurisdictional claims in published maps and institutional affiliations.

Copyright: (c) 2021 by the authors. Licensee MDPI, Basel, Switzerland. This article is an open access article distributed under the terms and conditions of the Creative Commons Attribution (CC BY) license (https:/ / creativecommons.org/licenses/by/ $4.0 /)$.

\begin{abstract}
Research highlights: Recreation value increases with the age of replanted as well as successional forests. Successional forests are not systematically less valuable for recreation than replanted forests. Succession may be used as a viable and low-cost reclamation practice of spoil heaps. Background and objectives: Afforestation has been a popular practice in post-mining land reclamation in the Czech Republic. To expand the current evidence on the recreation values of reclaimed forests, we conducted a valuation study for most typical reclaimed forests, as well as for successional forests spontaneously growing on surface coal mine deposit heaps. Using two distinct measurement methods, we also explore whether the estimated recreation value of forests is robust. Materials and Methods: An online survey was conducted in 2016 on a sample of residents living in the vicinity of coal mine deposit heaps, residents of the adjacent region of Karlovy Vary, and a control population from the central Bohemian region. Participants evaluated visual representations of forest stands typical for reclamation and succession, along with commercial spruce forest as a reference type. In the direct measurement, we measured the attractiveness of a respective forest for a walk using a 5-point scale. In the indirect measurement, a hypothetical choice between two forests for a walk was elicited in a discrete choice experiment. Results: Both direct and indirect measurements provide similar results. All reclaimed forests have a lower recreation value than the reference spruce forest. Successional forests are not systematically less valuable for recreation than replanted forests and the recreation value of both types increases with their age. The age, gender, and education of the participants did not affect the recreation value of a forest. Conclusions: We demonstrate that succession may be used as a viable and low-cost reclamation practice of spoil heaps emerging as a by-product of open-cast coal mining. With recreation as only one of many forest uses, our findings need to be interpreted vis-à-vis the objectives and expected results for individual sites and their habitat conditions.
\end{abstract}

Keywords: post-mining land reclamation; recreation value; successional forests

\section{Introduction}

\subsection{Post-Mining Reclamation}

Surface coal mines in Central Europe and elsewhere are examples of a vast intervention of human activity into the natural environment. To illustrate the scale of this impact, the total area of mining claims related to brown coal and lignite in the Czech Republic extended over $530 \mathrm{~km}^{2}$ in 1992; this has gradually shrunk to the current $236 \mathrm{~km}^{2}$ [1,2]. Extensive areas where mining activity was terminated have been transformed into forests, agricultural land, and artificial lakes. Afforestation has been a popular reclamation practice since the 1960s and results from the legal obligation of mining companies to reclaim land before it is made accessible to the public. Therefore, there are abundant reclaimed forests in the vicinity of several Czech cities. However, many of them are little used for recreation.

Weak demand for recreation in reclaimed forests (documented by a pilot observation in the study site) together with the substantial financial budgets allocated for this particular 
type of reclamation practice [3,4] raise the question of whether reclaimed forests (in the Czech Republic) are less valuable for recreation than commercial timber forests.

The body of research on preferences towards forests and their recreational values is large. It shows that the age of forest stands influence people's preference and that old forests are generally more valued (for the overview see $[5,6]$ ). The evidence about the preference for tree species and species composition is not unambiguous and strongly depends on the context of other factors, such as openness and visibility [6]. In some studies, pure pine and birch stands were preferred to others, e.g., [7-11]. Mixed stands were at least as attractive as one-tree-species stands in some studies [7], but see contradictory findings by [10]. Nevertheless, the existing research does not indicate how the recreational value of forests arising from mining disturbance and subsequent afforestation practices changes over time. Therefore, this study explores how various reclamation practices, including spontaneous succession and afforestation with one-tree-species, affects the recreation value, and how the value changes over time.

The examples of reclaimed forests existing in the Czech Republic are visually distinct from the most common types of both natural and commercial timber forests (cf. explanation below). A visual difference of reclaimed forests is one of the reasons why no applicable estimates of recreation values are available for a prospective benefit transfer.

There are economic values available of recreational benefits associated with naturebased and biodiversity-oriented forest management practices, e.g., [12,13]. However, these studies assess replacement of the baseline case stand of even-aged forests, not brandnew afforestation on formerly bare spoil heaps. Moreover, the valued nature-based management practice consists in passive protection with dead trees left for natural decay, not spontaneous successional growth of the forest. Moreover, the default situation of the afforested area is important for the valuation [6].

\subsection{Measuring Environmental Preferences}

Evaluation of environmental preferences is usually based on public preference for landscape, landscape type, element, or landscape characteristic e.g., [14,15]. Various methods are used for this measurement, one of the most used being evaluation of the attractiveness of visual, verbal, or other stimuli with psychometric measures e.g., [16-18]. Likert scale, or other psychometric scales, allows us to measure the intensity of liking (attractiveness) of the stimuli and, in relation to the wording of the respective statement, the willingness of individuals to spend time (live, work, etc.) in that environment.

Environmental preferences usually relate to a specific stimulus. According to its nature, two basic and commonly used evaluation methods can be distinguished-evaluation based on verbal stimuli and evaluation based on visual stimuli [19]. Static visual presentations, especially photographs, are frequently used as perceptual stimuli, the main reason being the financial and time-savings compared to field (in-situ) evaluation. Moreover, a visual presentation provides more options and greater variability on the part of both evaluated objects and evaluators. The use of photography as a perceptual stimulus is supported by a large number of studies [20-22], which point to a high positive correlation between landscape photography evaluation and in-situ landscape evaluation. Still, others consider the use of landscape photographs as perceptual stimuli to be insufficiently valid e.g., $[23,24]$. A direct measure of environmental preference, i.e., a single-item rating of perceived beauty [25,26], preference [27] or liking [28,29] of the stimuli has been successfully used in previous studies. We used a similar direct measure in our study for its simplicity and straightforwardness.

We can also portray environmental preferences as demand for services provided by the environment. This makes it possible to use a toolkit stemming from the theory of welfare economics [30]. Many of the services provided by the environment have no market value. Consequently, non-market valuation of environmental goods and services is used to measure these services [31]. Most often the strength of preference is expressed in the willingness to pay for a type of environment or for individual elements contained in 
it-recreation opportunity in the present study. The random utility theory then makes it possible to derive the recreational value of individual characteristics of the environment, and also to predict how the recreation demand and the benefits of people from recreation will change when the characteristics of the environment change e.g., [32]. Contingent valuation method and the discrete choice experiment are two frequently used methods of estimation of the recreation demand and its change based on the theory of welfare economics ([33-35]; see also [11,36-38] for evaluations of forests and forest management). A discrete choice experiment (henceforth DCE) was used also in our study. The main reason was that the DCE method allows us to derive change in preference (i.e., in probability of choice of the forest for recreation) due to a change in its characteristics, e.g., age of forest and the management approach.

\subsection{Research Purpose}

To expand the current evidence with estimates of recreation values of reclaimed forests we conduct a valuation study in which we gauge recreation value for the replanted monoculture forests (Norway spruce, Scots pine, and Black alder-the most widely planted tree species on soil heaps) as well as for successional forests spontaneously growing on surface coal mine deposit heaps. More specifically, we explore whether spontaneously growing successional forests on open-cast mine spoil heaps systematically differ in their recreation value from replanted forests and common commercial timber forests.

Moreover, this study explores if the type of reclamation (monoculture plantation and spontaneous succession) in interaction with the age of the forest affect its recreation value. In our endeavor, we take advantage of the fact that abundant examples of reclaimed forests are located in the Sokolov brown-coal basin in Western Bohemia in age stages ranging between 0 and 55 years.

Furthermore, we investigate whether the recreation value of forests growing on spoil heaps is affected by the origin of the forest, specifically by the information whether the forest is located in a mining area or not, and by the population which evaluates the forest.

Finally, we explore whether the estimated recreation value of a forest is robust to the method of measurement. Specifically, we used two distinct measures of recreation value: an ordinal rating of the perceived attractiveness of the forest for recreation and, in a discrete choice experiment based on random utility theory, a person's choice of a forest with different attributes for recreation.

\section{Materials and Methods}

\subsection{Study Site}

Sokolov coal basin is located in Western Bohemia, near the Ore Mountains (Krušné hory) and the German border. The heaps near Sokolov (approximately 23,000 inhabitants) were formed during the last 60 years by tertiary clay material, which was excavated from up to $200 \mathrm{~m}$ depth during opencast mining. The spoil heaps are different size, e.g., Podkrušnohorská heap is about $2.5 \mathrm{~km}$ wide and $10 \mathrm{~km}$ long. The location of the Sokolov spoil heap area within the Czech Republic is shown in Figure 1A and the geographical location of individual spoil heaps and investigated sites of forest stands in the Sokolov region is shown in Figure 1B. 


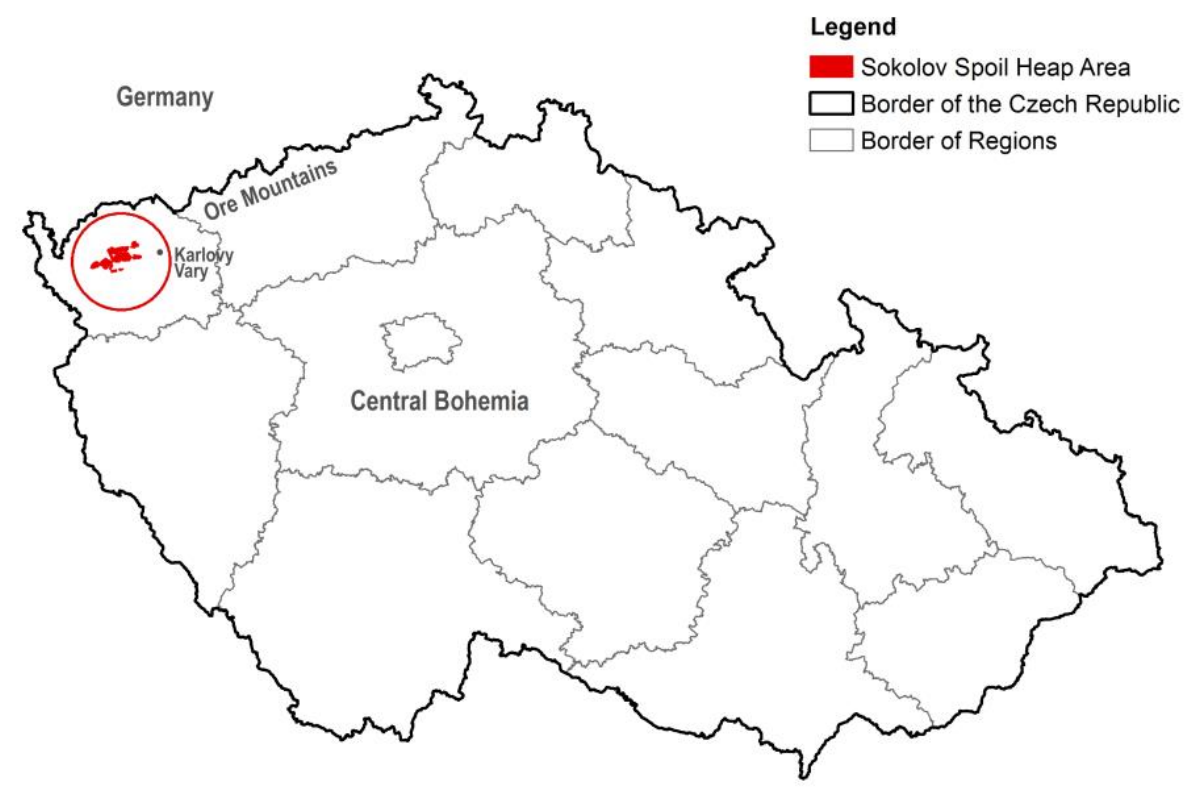

$1: 180,0000$

(A)

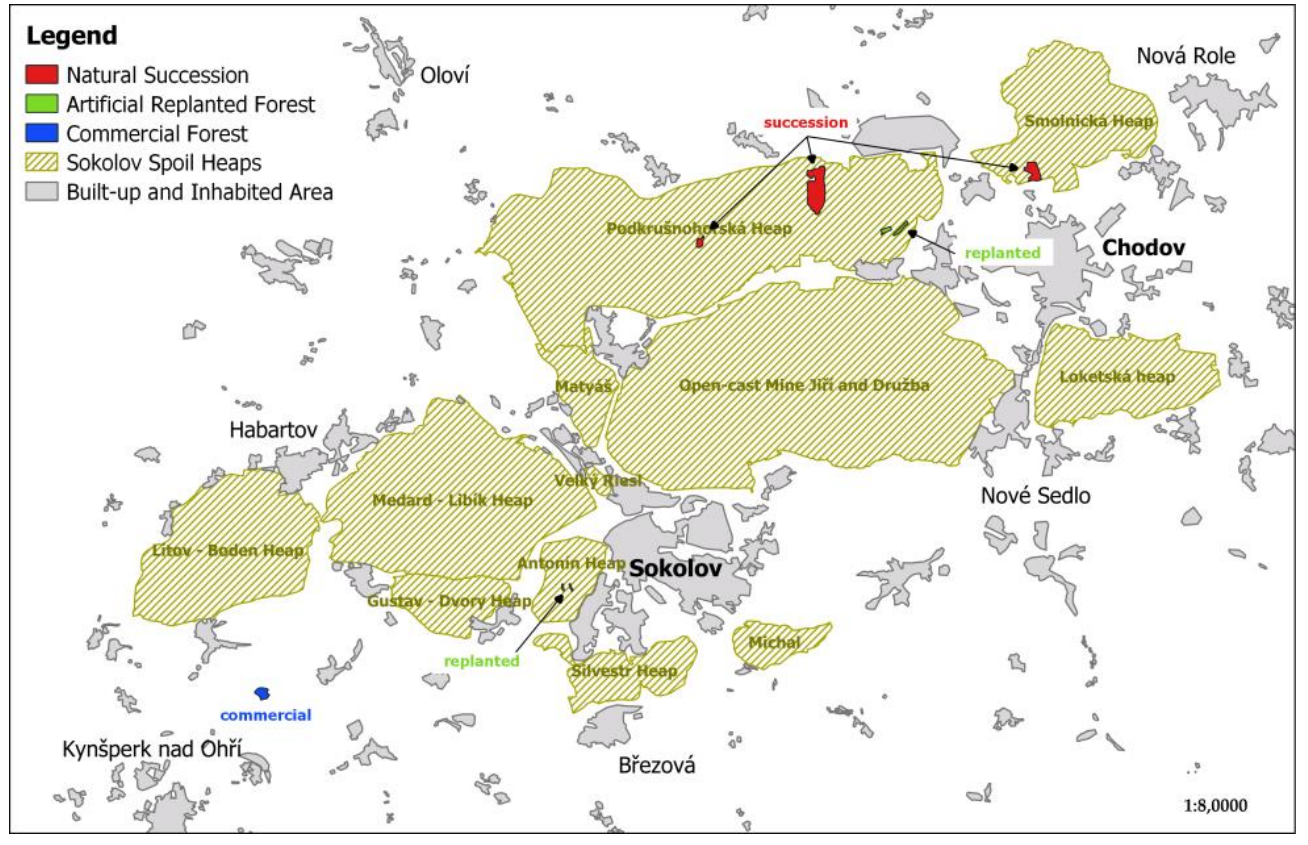

(B)

Figure 1. Study area. (A) The geographical position of the Sokolov spoil heap area in the Czech Republic; (B) the geographical location of individual spoil heaps and investigated sites of forest stands in the Sokolov region.

The heaps are covered by a mosaic of reclaimed and unreclaimed sites, where the terrain of reclaimed sites had been leveled before the tree were planted. Compared to that, no leveling had been carried out at the unreclaimed sites, where heaping machinery deposited overburden into a parallel series of waves (ridges and depressions), which are of different heights (from 1 to $5 \mathrm{~m}$ high) and several meters apart [39,40]. The geographical position of unreclaimed sites covered by spontaneous succession is illustrated for the 
Podkrušnohorská heap on the orthophoto map and the corresponding waves are shown on the photographs in Figure 2.
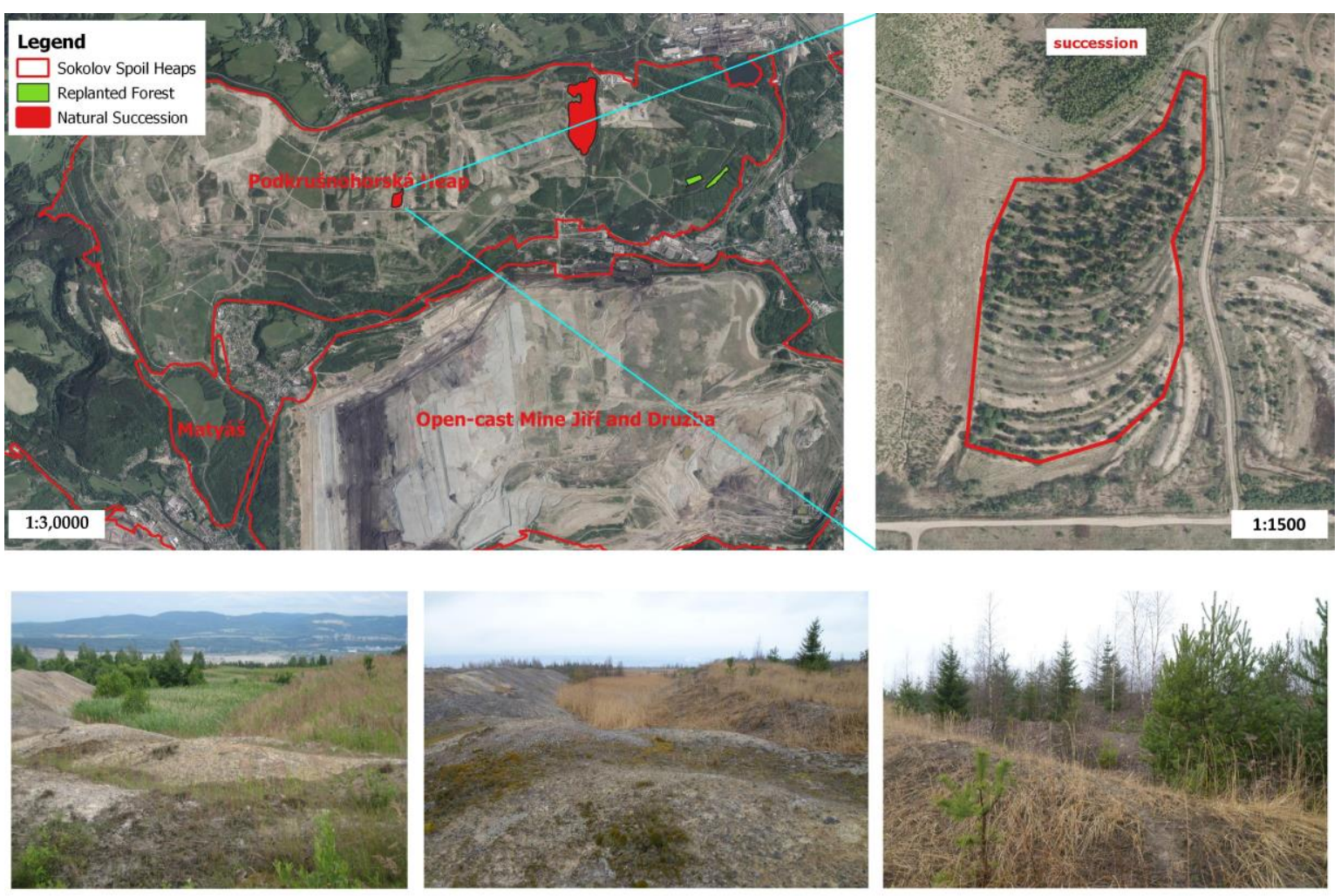

Figure 2. Geographical localization of unreclaimed sites on the Podkrušnohorská heap with and the visualization of wave-like terrain.

Heap vegetation is formed by a mosaic of forest stands (hereafter referred to as sites) of various species composition, age, and origin. Most of the sites have been reclaimed (afforested) by forest plantations (planted directly into the rough substrate), each dominated by one tree genus-usually Norway spruce (Picea abies (L.) H. Karst), Scots pine (Pinus sylvestris L.), common alder (Alnus glutinosa (L.) Gaertn.), or common oak (Quercus robur L.). Sites that have not been reclaimed are covered by spontaneously grown succession vegetation, mostly forests of varying ages.

\subsection{Participants}

An on-line questionnaire survey was administered to a sample from a proprietary panel of a survey company. Participants who filled out the questionnaire received remuneration. Data collection was conducted in 2016. The sample consisted of three strata of residents living in districts at different distances from the coal mine deposit heaps: (i) the population living in the vicinity of coal mine deposit heaps (Sokolov district); (ii) the population of the adjacent region of Karlovy Vary; and (iii) a control population (the most distant) from the Central Bohemian Region. Since there was no difference in any of the key variables between the populations living in the Sokolov district and the Karlovy Vary Region, both categories were collapsed in the subsequent analysis. According to the place of residence of a respondent, we further analyzed two categories of populations. The two categories were the local population, comprised of residents of the Sokolov district and Karlovy Vary Region, and a control population, comprised of residents from the Central Bohemian Region.

The resulting sample of 869 Czech adults was variable in terms of age $(M=42.8$, $S D=11.4)$, gender $(45.3 \%$ were males $)$, and education ( $55.1 \%$ had tertiary education). The resulting sample $(N=869)$ comprised 634 inhabitants from the Karlovy Vary Region 
$(73 \%)$ and a control group $(N=235 ; 27 \%)$ of inhabitants from the Central Bohemia Region. From the sample, $45.2 \%$ of the participants were living or had lived in mining-affected communities; the average number of years living in such a community was 36.7 years $(S D=14.8)$. The completion rate was $70.1 \%$.

\subsection{Materials}

\subsubsection{Evaluated Forests and Their Visual Representations}

The on-line electronic questionnaire employed visual representations of seven forest stands typical for so-called reclamation management of spoil heaps in the mining district of Sokolov and one reference commercial forest stand from a location not affected by mining. The reclaimed forests represent typical results of two reclamation practices with different tree species and in different age classes that can be found on deposit heaps in the Sokolov coal basin. The first reclamation practice is the plantation of a forest homogeneous in terms of a single tree species planted at one point of time (henceforth, replantation or replanted forests). In the present study, the plantation practice was represented by spruce replantation in two age classes (15 and 35 years), alder replantation at the age of 35 years, and pine replantation at the age of 35 years. The second reclamation practice, used so far only for experimental purposes, is a spontaneous succession (henceforth 'succession' or 'successional forest') and, in the present study, was represented by three age classes (15, 35, and 55 years). Additionally, a commercial spruce forest (75 years of age), representing the most typical forest stand used for recreation in the Czech Republic was evaluated as a reference forest type. See the characteristics of evaluated forests in Table 1.

Table 1. Evaluated forest types.

\begin{tabular}{|c|c|c|c|}
\hline \multirow{2}{*}{$\begin{array}{l}\text { Acronym of } \\
\text { Forest Type }{ }^{1}\end{array}$} & \multicolumn{3}{|c|}{ Attributes } \\
\hline & Prevailing Tree Species 4 & Origin of the Forest 5,6 & Age $e^{5,7}$ \\
\hline \multicolumn{4}{|c|}{ Reference commercial timber forest: } \\
\hline Spr75 & spruce & commercial timber forest & 75 years \\
\hline \multicolumn{4}{|c|}{ Reclaimed forest: } \\
\hline Spr35 2 & spruce & planted on an open-cast coal mine spoil heap & 35 years \\
\hline Spr15 ${ }^{2}$ & spruce & planted on an open-cast coal mine spoil heap & 15 years \\
\hline Pin35 & pine & planted on an open-cast coal mine spoil heap & 35 years \\
\hline Ald35 & alder & planted on an open-cast coal mine spoil heap & 35 years \\
\hline \multicolumn{4}{|c|}{ Unmanaged forest: } \\
\hline Suc55 & mixed & $\begin{array}{l}\text { spontaneously growing on an open-cast coal } \\
\text { mine spoil heap }\end{array}$ & 55 years \\
\hline Suc35 3 & mixed & $\begin{array}{l}\text { spontaneously growing on an open-cast coal } \\
\text { mine spoil heap }\end{array}$ & 35 years \\
\hline Suc15 3 & mixed & $\begin{array}{l}\text { spontaneously growing on an open-cast coal } \\
\text { mine spoil heap }\end{array}$ & 15 years \\
\hline
\end{tabular}

Note: ${ }^{1}$ The number in the acronym indicates the age of the forest. ${ }^{2}$ These two spruce forests were evaluated in Part 2 only. ${ }^{3}$ This forest type was in Part 1 evaluated by only one-half of the sample. ${ }^{4}$ This attribute determining the prevailing tree species was visible only in photographs. ${ }^{5}$ This attribute was described by the label. 6 The attribute "origin of the forest" was a factor in Part 1 and a label in Part 2 in the questionnaire. 7 The attribute as the age was a label in Part 2 in the questionnaire.

The selection of forests evaluated in this study was based on: (i) a sample of expertevaluated forest stands typical for forest reclamation in the Sokolov district and hence available for photographing; and (ii) an on-site field survey of distinctive visual characteristics of the forest stands.

Each of the evaluated forests was represented in the questionnaire by a quartet of color photographs of the stand taken on the deposit heaps in the Sokolov district during summer 2016. Photographs of the reference spruce stand were taken in Libavske valley in the same region. Employment of photographs as valid and adequate stimuli for evaluation of environmental preferences has been documented, e.g., by [22]. We used the quartet of photographs to show the natural diversity of the stands in order to capture variation in each forest type appearance; see, e.g., [28,41,42]. We photographed the stands from inside to minimize the effect of the path and natural boundaries (or barriers) of the stand. Except for the regular planting of trees in rows in replanted forests, no other manifestations 
of human presence or ephemeral elements were visible in the photographs (see visual representations of the evaluated forests in Figure A1 in Appendix A).

\subsubsection{Measures of Recreation Value of Reclaimed Forests}

In this study, two distinct measures were used to estimate recreation values of reclaimed forests: (i) rating of the perceived attractiveness of forests for recreation (henceforth, the direct measure), and (ii) a person's choice of a hypothetical locality for recreation (henceforth, the indirect measure), both in response to the particular visual stimuli. Both measures were based on the stated preference approach to the valuation of environmental goods and services [43]. The stated preference approach was most convenient for our study as entry to (forest) areas on coal mine spoil heaps is prohibited for safety reasons until 35 years after the completion of the dump.

The direct measures assessed environmental preference [17] and consisted of one item asking a respondent about the attractiveness of the forest displayed on a quartet of photographs on a 5-point scale ranging from $-2=$ not at all attractive to $2=$ very attractive. Precisely, we asked: "How attractive would it be for you to walk one hour on the pathway in this forest?" Walking for one hour as a reference frame for the environmental preference was chosen, as it is possible in all types of environments and usually does not require special physical abilities, knowledge, or attention [16,17]. Six selected forest stands out of the total eight were evaluated by the direct measure in Part 1 of the questionnaire (see Table 1).

The indirect measure assessed a person's choice of a forested locality for recreation obtained in a simple discrete choice experiment. DCE is a special type of survey that presents hypothetical choice tasks to respondents and allows us to estimate the impact of characteristics of the choice alternatives (called attributes) on a person's choice [44]. The preferred alternative in each choice task is analyzed by means of statistical analysis, commonly multinomial or conditional logit model e.g., [45]. The choice task in DCE said: "Imagine a one-hour walk on a path in a forest. Which one out of the following two localities would you choose? Both localities may also differ in the access time to the locality". The choice task had two alternative localities for recreation and an opt-out alternative worded as: "I would rather stay at home". The alternatives in DCE were characterized by three attributes: type of the forest stand represented by the tree species on the photographs, age stage of the forest, and access time to the locality. Access time in minutes of walk indicated behavioral costs related to the particular alternative and had the following four levels: 5, 10, 20, and $25 \mathrm{~min}$. The age class of the forest stand did not vary orthogonally across the tree species displayed on the photographs, but additionally characterized a particular forest type. In effect, an example of a forest evaluated in DCE was a 35-year-old forest planted on an open-cast coal mine spoil heap, which was represented by a quartet of photographs with spruce forest stands. The labels above the photographs additionally described the forest type and the age class. An example of the choice experiment question is displayed in Figure 3. Note that the design of the DCE had to account for the fact that only selected combinations of forest type (i.e., prevailing species of trees), age class, and origin of the forests (spontaneously growing or planted) exist and were thus available for photographing (see Table 1).

The multinomial choice model formulation was used to test the hypotheses about the impact of forest attributes and access time to the locality on a person's choice of the forest for recreation.

\section{Origin of the Forest}

The origin of the forest was included in a label above the visual stimuli (see Figure 3), which was shown to half of the sample in Part 1 (direct measure) and all participants in Part 2 (indirect measure-DCE). The label said either spontaneously growing or planted forest on an open-cast coal mine spoil heap. The presence of the label was varied in Part 1 of 
the questionnaire to test a hypothesis about the negative effect of mining on the recreation values beyond the effect of visual characteristics of the forest.

Imagine a one-hour walk on a path in forest. Which one out of the following two localities would you choose? Both localities may also differ in the time to assess the locality.

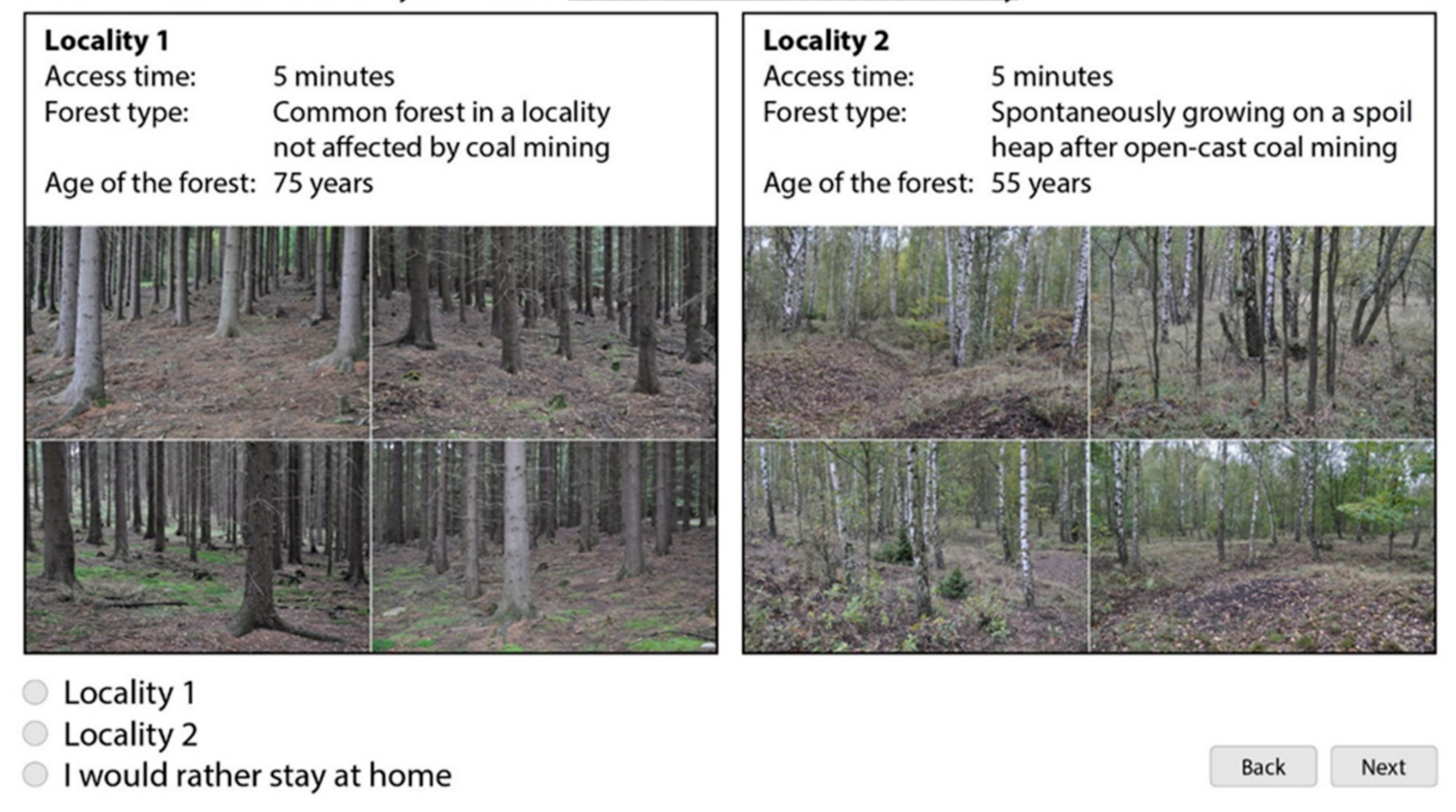

Figure 3. Example of choice experiment question.

Age of the Forest

The age of the forest was represented by the photographs of a particular stand of that age taken in the study area. Furthermore, the age of the forest was displayed as an additional attribute of the choice alternatives above the quarter of photographs in DCE in Part 2. The age attribute had four levels $(15,35,55$, and 75 years), but we estimated the effect of age in years as a continuous variable in the multinomial logistic regression.

\subsection{Design and Procedure}

The survey had a combined design. The respondent approached the questionnaire online. First, each respondent was randomly assigned to an experimental condition in Part 1. After finishing Part 1 the respondent was again and independently of the assignment in Part 1 randomly assigned to an experimental condition in Part 2.

In Part 1, all participants were first shown a quartet of photographs representing five forest types (Norway spruce, Scots pine, Black alder, White birch, and Goat willowdominant tree species growing on spoil heaps as can be seen in Figure A1 in Appendix A). They could look at them for as long as they wanted. The photographs were displayed in a random order, which was the same in the subsequent questions as in Part 1. Part 1 had a $2 \times 2$ factorial between-subject design, i.e., each participant was randomly assigned to one of four experimental conditions (see Table A1 in Appendix A for the design specification). The first manipulated factor was the type of forest displayed as the fifth evaluated forest (successional forest at age 15 years vs. at age 35 years); the preceding four forest types were identical for everybody. The other factor was the display of information on the origin of the forest (displayed vs. not displayed). After looking at the photographs, participants evaluated forests with respect to five visual features (not reported in the present study). Afterward, participants evaluated the forests with the direct measure of attractiveness for recreation. 
Part 2 consisted of a DCE in which participants evaluated six forest types from Part 1 and two extra forest types (see Table 1). Participants were randomly assigned to one of four blocks and went through eight choice tasks. In the DCE, a choice of a hypothetical locality for a short walk was presented to participants. The choice task consisted of two alternative localities and an opt-out alternative.

In Part 3, participants were debriefed and asked about their socio-demographics.

\section{Results}

The following section presents estimates of the recreation value of reclaimed forests growing on open-cast coal mine spoil heaps with the two distinct measures described above. We present the results of an ordinal logit model with the direct measures of recreation values first, followed by those of a multinomial logit model with the indirect measure employed in DCE. A description of all variables entered into the regression models and their types is listed for illustration in Table 2. The data used in the regression models are available in Supplementary Materials.

Table 2. Description of variables used in the regression models.

\begin{tabular}{|c|c|c|}
\hline Variable Name & Type & Description \\
\hline \multicolumn{3}{|r|}{ Ordinal logistic regression } \\
\hline Attractiveness ${ }^{1}$ & ordinal & $\begin{array}{l}\text { How would you like walking on forest way in this forest for } \\
\text { one hour? (from }-2=\text { not at all to }+2=\text { very attractive) }\end{array}$ \\
\hline Spr75 2 & dummy & commercial spruce forest at age 75 years as reference forest \\
\hline Suc15 & dummy & $1=$ natural succession at age 15 years; $0=$ other forest types \\
\hline Suc35 & dummy & $1=$ natural succession at age 35 years; $0=$ other forest types \\
\hline Suc55 & dummy & $1=$ natural succession at age 55 years; $0=$ other forest types \\
\hline Ald35 & dummy & $1=$ alder plantation at age 35 years; $0=$ other forest types \\
\hline Pin35 & dummy & $1=$ pine plantation at age 35 years; $0=$ other forest types \\
\hline Order & ordinal & $\begin{array}{l}\text { higher of order, in which the forest was evaluated in Part } 1 \\
(1=\text { the first in evaluation; } 5=\text { the last in evaluation }) \\
\text { information on the origin of the forest, if the forest has been }\end{array}$ \\
\hline Label & dummy & $\begin{array}{l}\text { replanted or has been spontaneously growing on spoil heaps } \\
(1=\text { information was present; } 0=\text { without information })\end{array}$ \\
\hline \multicolumn{3}{|c|}{ Multinomial logistic regression } \\
\hline Choice $^{1}$ & dummy & choice realized in $\mathrm{DCE}^{3}(1=$ true $; 0=$ false $)$ \\
\hline Spruce & dummy & $1=$ spruce forests at all ages; $0=$ other forest types \\
\hline Succession & dummy & $1=$ natural succession at all ages; $0=$ other forest types \\
\hline Ald35 & dummy & $1=$ alder plantation at age 35 years; $0=$ other forest types \\
\hline Pin35 & dummy & $1=$ pine plantation at age 35 years; $0=$ other forest types \\
\hline Mine & dummy & $\begin{array}{c}1=\text { forest growing on spoil heap; } 0=\text { commercial forest growing } \\
\text { outside the spoil heap }\end{array}$ \\
\hline Age & cardinal & age class of the forest stand $(15,35,55,75$ years $)$ \\
\hline Time & cardinal & access time of walk to the locality $(5,10,20,25 \mathrm{~min})$ \\
\hline Left & dummy & $\begin{array}{l}\text { position of the forest on the left vs. right hand card in } \mathrm{DCE}^{3} \\
\qquad(1=\text { left; } 0=\text { right })\end{array}$ \\
\hline \multicolumn{3}{|c|}{ Socio-demographic variables in both models } \\
\hline KV_reg & dummy & $\begin{array}{c}1=\text { local population (Sokolov district and Karlovy Vary Region; } \\
0=\text { control population (Central Bohemian Region) }\end{array}$ \\
\hline Gender & dummy & $1=$ male; $0=$ female \\
\hline College & dummy & $1=$ university education; $0=$ other \\
\hline Age_pop & cardinal & age of a respondent \\
\hline
\end{tabular}

Note: ${ }^{1}$ Dependent variable in the regression, ${ }^{2}$ Control variable in the regression, ${ }^{3}$ DCE stands for Discrete Choice Experiment.

\subsection{Direct Measure of Recreation Value-Rating of Forest Attractiveness}

\subsubsection{Mean Ratings of Recreation Value}

An overview of the average ratings of the attractiveness of all forests for the two subpopulations-local and control population-is displayed in Figure 4. The average rating of attractiveness of the reference forest (Spr75) reached $M=1.01, S D=1.13,95 \% \mathrm{CI}$ $(0.93,1.08)$; that of pine reclamation $(\operatorname{Pin} 35), M=0.39, S D=1.08,95 \% \mathrm{CI}(0.32,0.47)$; and that of 15-year-old succession (Suc15) as low as $M=-0.24, S D=1.25,95 \%$ CI $(-0.36,-0.12)$. 


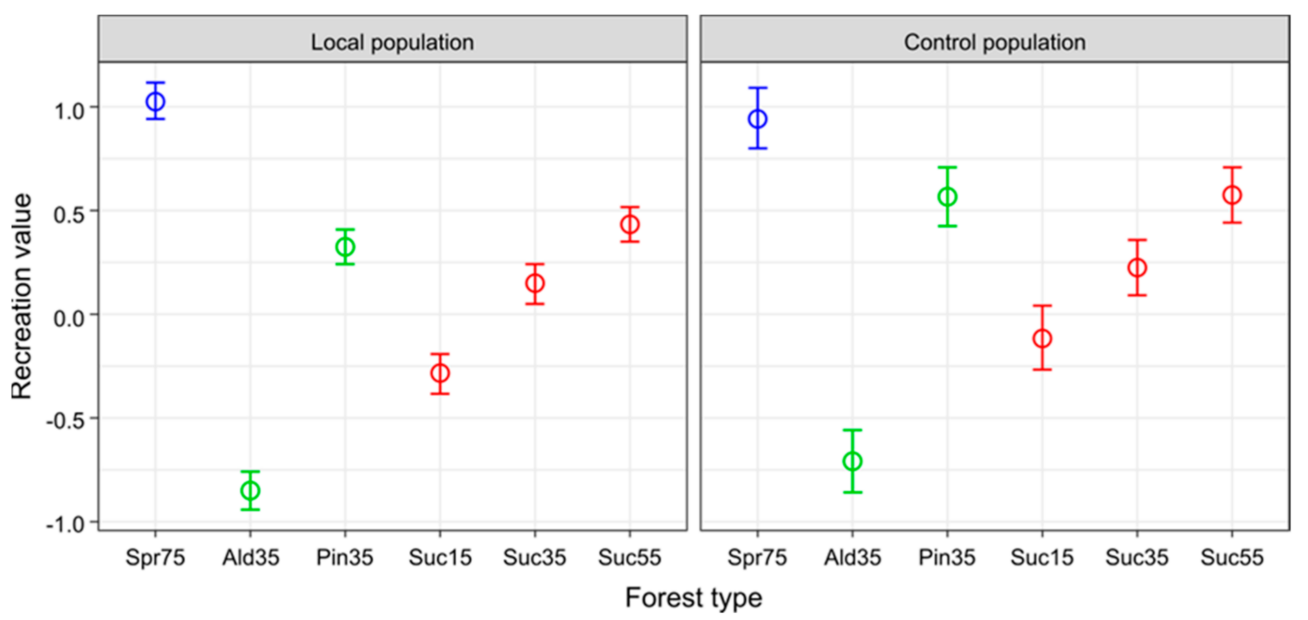

Figure 4. Mean ratings of recreation value of reclaimed forests in the local and the control population (measured directly). Direct measure assessed recreation value with a one-item rating of the attractiveness of the forest on a five-point scale $(-2=$ not at all attractive to $2=$ very attractive $)$. Spr75 is a 75 -year-old reference commercial timber forest. Whiskers display $95 \%$ confidence intervals for means.

The average rating of the 55-year-old successional forest (Suc55) was comparable with the recreation value of the 35-year-old re-planted pine forest (Pin35), $M=0.47, S D=1.07$, $95 \% \mathrm{CI}(0.40,0.54)$ and $M=0.39, S D=1.08,95 \% \mathrm{CI}(0.32,0.47)$, respectively. The differences in mean attractiveness ratings of the successional forests indicated that the recreation value is affected by the age of the forests. While the average rating of attractiveness of the 15-year-old successional forest (Suc15) was $M=-0.24, S D=1.25,95 \%$ CI $(-0.36,-0.12)$ and of the 35-year-old (Suc35) $M=0.17, S D=1.16,95 \%$ CI $(0.06,0.28)$, the 55-year-old successional forest (Suc55) had the highest average rating of attractiveness, $M=0.47$, $S D=1.07,95 \%$ CI $(0.40,0.54)$.

The mean recreation value of a forest growing on coal mining spoil heaps differed between the control and the local population of the mining region Karlovy Vary (see Figure 4). Local people rated the attractiveness of all post-mining forests lower than people from far away, but the difference in the mean recreation value was, however, statistically significant only for the replanted pine forest (Pin35). Still, differences between the recreation value of succession and replanted forests are rather similar in the local and control populations.

\subsubsection{Ordinal Regression Model}

The results of the ordinal logit model demonstrate that the recreation value of all forests growing on open-cast coal mine spoil heaps significantly differs from the recreation value of a commercial timber forest, which was set as a reference forest in the model (see the estimates of ordinal logistic regression model in Table 3).

The recreation value of all three age variants of successional forests was lower than that of the reference spruce forest at the age of 75 years (Spr75) (control variable in the ordinal logistic regression model). For instance, even the most attractive 55-year-old successional forest (Suc55) was rated lower than the reference forest, $B=-0.69, \mathrm{OR}=0.50,95 \% \mathrm{CI}(0.33$, $0.77), z=-3.21, p=0.001$. Importantly, the recreation value of the successional forests was not systematically lower than the recreation values of the replanted forests. 
Table 3. Ordinal logistic regression model.

\begin{tabular}{|c|c|c|c|c|c|c|}
\hline \multirow[t]{2}{*}{ Variable } & \multirow{2}{*}{ Beta } & \multirow[t]{2}{*}{ OR } & \multicolumn{2}{|c|}{$95 \% \mathrm{CI}$} & \multirow[t]{2}{*}{$z$} & \multirow[t]{2}{*}{$p$-Value } \\
\hline & & & Lower Bound & Upper Bound & & \\
\hline Suc15 & -2.070 & 0.130 & 0.070 & 0.210 & -7.720 & 0.000 \\
\hline Suc35 & -1.390 & 0.250 & 0.150 & 0.410 & -5.500 & 0.000 \\
\hline Suc55 & -0.690 & 0.500 & 0.330 & 0.770 & -3.210 & 0.001 \\
\hline Ald35 & -2.920 & 0.050 & 0.030 & 0.080 & -13.210 & 0.000 \\
\hline Pin 35 & -0.700 & 0.500 & 0.330 & 0.760 & -3.250 & 0.001 \\
\hline Order & 0.060 & 1.060 & 1.020 & 1.110 & 2.840 & 0.005 \\
\hline Label & -0.030 & 0.970 & 0.860 & 1.090 & -0.560 & 0.573 \\
\hline KV_reg & 0.020 & 1.020 & 0.720 & 1.450 & 0.130 & 0.896 \\
\hline Gender & 0.020 & 1.020 & 0.910 & 1.150 & 0.330 & 0.742 \\
\hline College & 0.010 & 1.010 & 0.860 & 1.180 & 0.130 & 0.898 \\
\hline Age_pop & 0.000 & 1.000 & 0.990 & 1.000 & -1.690 & 0.090 \\
\hline Suc15*KV_reg & -0.150 & 0.860 & 0.480 & 1.540 & -0.510 & 0.608 \\
\hline Suc35*KV_reg & -0.110 & 0.890 & 0.510 & 1.550 & -0.400 & 0.689 \\
\hline Suc55*KV_reg & -0.440 & 0.640 & 0.400 & 1.020 & -1.860 & 0.063 \\
\hline Ald $35^{*} \mathrm{KV}$ reg & -0.200 & 0.820 & 0.510 & 1.320 & -0.820 & 0.413 \\
\hline Pin35*KV_reg & -0.560 & 0.570 & 0.360 & 0.920 & -2.330 & 0.020 \\
\hline \multicolumn{7}{|l|}{ Cutpoints: } \\
\hline$-2 \mid-1$ & -3.610 & 0.030 & & & & \\
\hline$-1 \mid 0$ & -2.410 & 0.090 & & & & \\
\hline $0 \mid 1$ & -1.030 & 0.360 & & & & \\
\hline $1 \mid 2$ & 0.310 & 1.370 & & & & \\
\hline
\end{tabular}

Moreover, the recreation values of forests replanted on coal mine deposit heaps were lower than that of the reference forest. Even the recreation value of the most attractive pine reclamation (Pin35) was lower than that of the reference forest, $B=-0.70, O R=0.50$, $95 \% \mathrm{CI}(0.33,0.76), z=-3.25, p=0.001$, and for alder forest (Ald35) even lower, $B=-2.91$, $O R=0.05,95 \% \mathrm{CI}(0.03,0.08), z=-13.21, p<0.001$. Apparently, the forests replanted on open-cast coal mine spoil heaps differed substantially from each other depending on the type of forest represented by tree species and age.

The statistical significance was apparent between the recreation values of the replanted pine forest assessed by the local and control population (Pin $\left.35^{*} \mathrm{KV} \_r e g\right), B=-0.56$, $O R=0.57,95 \% \mathrm{CI}(0.36,0.92), z=-2.33, p=0.020$; the statistical difference between these two sub-populations has not been proved by the model for other types of succession and replanted forests.

Notably, none of the common sociodemographic variables (Gender, Age_pop, and College) accounted for the difference in the recreation value of reclaimed forests between both populations.

From the methodological variables, the recreation value of the forest was positively affected by the higher order (Order), in which the forest was evaluated, $B=0.06, O R=1.06$, $95 \% \mathrm{CI}(1.02,1.11), z=2.84, p=0.005$. However, this effect was rather small. The information on the origin of the forest (Label), i.e., that it has been replanted or has been spontaneously growing on open-cast coal mine spoil heaps did not affected the recreation value, $B=-0.03$, OR $=0.97,95 \%$ CI $(0.86,1.09), z=-0.56, p=0.57$.

To sum up, when measured directly, all reclaimed forests had a lower recreation value than the reference spruce forest, which was, however, one class older than the oldest reclaimed forest ( 75 vs. 55 years old). The successional forests were not systematically less valuable for recreation than replanted forests and the recreation value increased with their age. Moreover, successional forests seem to need more time to gain a high recreation value than replanted forests.

\subsection{Indirect Measure of Recreation Value-Choice of a Locality for Recreation}

\subsubsection{Multinomial Regression Model}

The multinomial logit model (henceforth MNL) with two additional age variants of the replanted spruce forest (15 and 35-year-old) enabled us to separate the effect of forest type (for succession and replanted spruce forest) from the effect of age (see the estimates of MNL model in Table 4). 
Table 4. Multinomial logistic regression model.

\begin{tabular}{ccccccc}
\hline Variable & Beta & OR & \multicolumn{2}{c}{$\mathbf{9 5 \% \text { CI }}$} & $z$ & $p$-Value \\
& & & Lower Bound & Upper Bound & & \\
\hline Spruce & 3.324 & 27.782 & 3.082 & 3.567 & 26.87 & 0.000 \\
Spruce*Mine & -4.007 & 0.018 & -4.337 & -3.678 & -23.83 & 0.000 \\
Spruce*Mine*Age & 0.098 & 1.103 & 0.091 & 0.106 & 24.83 & 0.000 \\
Spruce*KV_reg & 0.479 & 1.614 & 0.225 & 0.733 & 3.69 & 0.000 \\
Spruce*Mine*KV_reg & -0.489 & 0.613 & -0.795 & -0.182 & -3.13 & 0.002 \\
Succession & 1.342 & 3.826 & 1.142 & 1.542 & 13.14 & 0.000 \\
Succession*Age & 0.023 & 1.023 & 0.019 & 0.026 & 12.82 & 0.000 \\
Succession*KV_reg & -0.128 & 0.880 & -0.253 & -0.003 & -2.01 & 0.045 \\
Pin35 & 2.258 & 9.563 & 2.040 & 2.476 & 20.32 & 0.000 \\
Pin35*KV_reg & -0.096 & 0.908 & -0.307 & 0.114 & -0.9 & 0.370 \\
Ald35 & 0.894 & 2.444 & 0.644 & 1.143 & 7.02 & 0.000 \\
Ald35*KV_reg & -0.343 & 0.710 & -0.613 & -0.073 & -2.49 & 0.013 \\
Time & -0.001 & 0.999 & -0.006 & 0.004 & -0.43 & 0.670 \\
Left & 0.116 & 1.123 & 0.042 & 0.190 & 3.07 & 0.002 \\
Gender & -0.008 & 0.992 & -0.075 & 0.060 & -0.22 & 0.824 \\
College & 0.012 & 1.012 & -0.074 & 0.098 & 0.26 & 0.792 \\
Age_pop & $6.38 \times 15^{-6}$ & 1.000 & -0.003 & 0.003 & 0 & 0.997 \\
\hline Constant & -2.295 & - & -2.448 & -2.141 & -29.33 & 0.000 \\
\hline
\end{tabular}

The results revealed that the recreation value of any successional forests was higher than the value of the reference option of staying at home (Succession), $B=1.34, O R=3.82$, $95 \%$ CI $(1.14,1.54), z=13.14, p<0.001$ and also that the value of successional forests increases with every year of age (Succession ${ }^{*}$ Age), $B=0.02, O R=1.02,95 \%$ CI $(0.02,0.03)$, $z=12.82, p<0.001$. Note, that the recreation value of the replanted spruce forest also increases with every year of age $\left(\right.$ Spruce $^{*}$ Mine $\left.^{*} A g e\right), B=0.10, O R=1.10,95 \%$ CI $(0.09$, 1.11), $z=24.83, p<0.001$. In fact, the effect of age on the recreation value of a replanted spruce forest is larger than the effect of age on the value of a successional forest. In effect, the spruce replantation gains on recreation value every year more than the succession.

Moreover, recreation values of pine (Pin35) and alder replantation (Ald35) were higher than the value of the reference option of staying at home, $B=2.26, O R=9.56,95 \% \mathrm{CI}$ $(2.04,2.48), z=20.32, p<0.001$, and $B=0.89, O R=2.44,95 \%$ CI $(0.64,1.14), z=7.02$, $p<0.001$, respectively.

The recreation value of the replanted spruce forest (Spruce ${ }^{*}$ ine $e^{*} K{ }_{-}$reg), alder (Ald35*KV_reg), and the successional forest (Succession ${ }^{*} K V \_r e g$ ) were lower for the local population than for the control population.

Contrary to our expectations and a frequented DCE model with travel time (Time) as a proxy of (travel) costs, the recreation value of the forest was not affected by the access time, $B=-0.001, O R=1.00,95 \%$ CI $(-0.01,0.00), z=-0.43, p=0.67$.

Consistent with the finding from the direct measure, the recreation value of the forest was not affected by the age (Age_pop), gender (Gender), or education (College) of the participants.

Importantly methodological variables, such as position of the forest on the left vs. right hand card in DCE (Left), affected significantly the estimated recreation value of the forest, $B=0.12, O R=1.12,95 \%$ CI $(0.04,1.19), z=3.07, p=0.002$.

\subsubsection{Predicted Recreation Values}

In a subsequent step, we used the multinomial logit model to predict the mean choice probability of forests (representing a relative measure of recreation value) compared to an opt-out choice of staying at home, depicted in Figure 5. As the effect of age adds to the generic effect of replanted spruce and succession, the effect of these two forest types cannot be directly compared with the effects of tree types with only one age variant, i.e., alder and pine. Still, the model allows for predicting recreation values for replanted spruce and succession forests types at ages not present in the portfolio evaluated by respondents (namely replanted spruce forest 55 years old, and unmanaged succession 75 years old). 


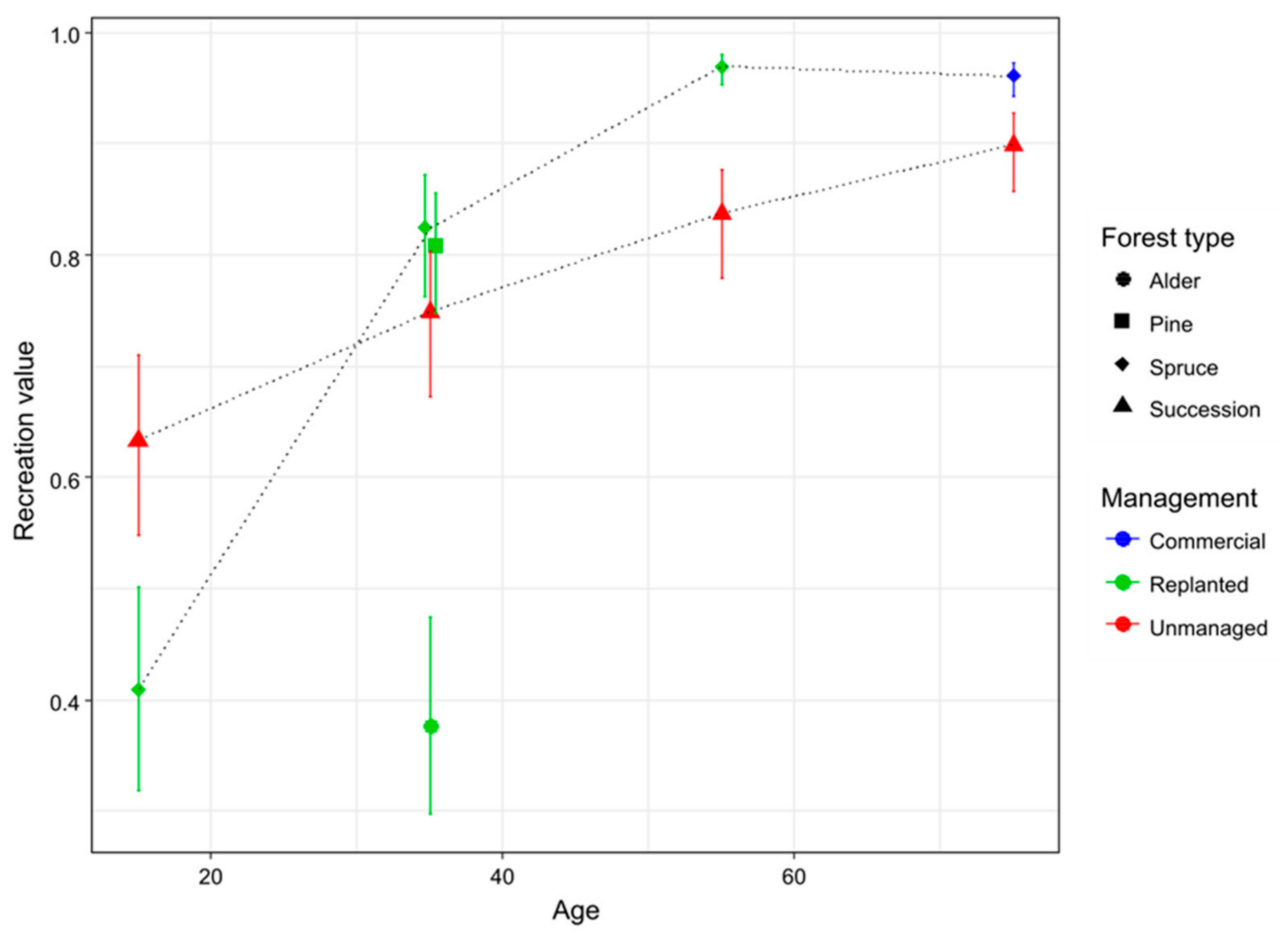

Figure 5. Mean recreation values of reclaimed forests (measured indirectly and predicted by multinomial logit model (MNL)). Indirect measure assessed recreation value with a person's choice of a locality for recreation in a discrete choice experiment. The symbols of forest types display the mean choice probability of forests compared to an opt-out choice of Scheme 95. confidence intervals for means.

We observe the highest mean recreation values for mature spruce forests and mature succession forests. For both types the predicted recreation values are not significantly different at 55 and 75 years of age, yet mature spruce forest type remain significantly more attractive compared to succession forest type.

The recreation value of alder reclamation at the age of 35 years was much lower than the recreation value of replanted (spruce and pine) and succession forests at the same age, corresponding to the ranking observed using direct measure (see Figure 4).

\section{Discussion}

\subsection{Recreation Value of Successional Forests}

The purpose of this study was to examine the recreation value of forest, which came into existence as a result of two distinct practices of reclamation of open-cast coal mine spoil heaps. Specifically, we examined the recreation value of forests growing spontaneously compared to forests replanted with different tree species after the closure of the coal mines. We were interested in whether the recreation value of the successional forest is systematically lower than that of the replanted forest and how much both recreation values differ from that of the commercial timber forest used for recreation in the neighboring area. The results of the present study clearly and consistently indicate that successional forests are as attractive for recreation as the replanted forests and that their recreation value, similarly to the recreation value of other types of forests, significantly increases with the age of the forest. This is generally consistent with the findings of many other studies, e.g., [46,47]. It also means that the recreation value of early-stage forests is rather low. Interestingly, the low recreation values in the initial stages of forests are not specific for succession but also replanted forests [25]. In fact, the recreation value of spruce reclamation at the age of 15 years was lower than the recreation value of succession forests at the same age, probably reflecting a low attractiveness of thick and impenetrable young replanted spruce forests (a common foresters' practice) compared to relatively loose succession forests. 
Furthermore, the recreation value of successional forests increasing with their age indicates that they may approach the recreation value of the commercial timber forest used for recreation elsewhere after about 80 years (at about timber rotation period) (see Figure 5). Note that, so far, no successional forests in this age exist on (post-)mining sites in the Czech Republic that we could have used in our research as visual stimuli. To have even stronger evidence that the unmanaged succession process itself can create as attractive a forest on spoil heaps for recreation as a replanted forest can, successional forests should be examined again after the next 20 years when they reach the typical age of a forest used for recreation elsewhere.

The results of the current study also indicate that different populations may differ in the values, which they attribute to recreation in reclaimed forests. Even if differences in recreation values between the local and the control population were not entirely consistent across both measures, i.e., the difference in the value of some forests was not statistically significant when measured directly, they indicate that the local population may associate reclaimed forests with negative attributes (such as toxic soil or waste after mining activity) even if they are not visible on the photographs. Such effects of non-visible negative attributes of reclaimed forest on their attractiveness deserve further investigation as it may limit the actual recreation value of the forests on sites after an anthropogenic disturbance.

As shown in a study by [48], association of reclaimed forests with negative attributes has been indicated by a negative effect of the information about the location in the postmining area on the preference. However, this study did not provide direct evidence, as the location in the post-mining area and the forest type were not orthogonal factors. In order to obtain direct evidence on the influence of non-visible attributes, it would be necessary to use research design where the location of the forest and the evaluated forest type would represent two independently manipulated attributes.

\subsection{The Method}

The findings in the current study concerning the recreation value of forests on opencast mine spoil heaps were consistent across two distinct measures of the recreation value, namely ordinal rating of attractiveness and a person's choice of a locality for recreation in the discrete choice experiment. Both methods indicate that the recreation value of forests growing on coal mine spoil heaps does not reach the value of the reference commercial timber forest. Both measures revealed that alder replantation is the least attractive and that the value of successional forest considerably increases over time.

Such consistency of the results implies that the ordinal rating of the attractiveness of a forest for recreation, a much simpler method, may provide as valid results as a rather complicated DCE. However, the DCE not only confirms that there is a difference in preferences for different forests, but also shows what the magnitude of the differences in preferences is [12]. Moreover, the estimates based on the DCE show that the recreation value of spruce forest increases more steeply in the middle age, i.e., between 15 and 35 years, than in the older-age, i.e., between 35 and 55 years (see Figure 5). Such an increase in the value of the middle-aged spruce forest may be a result of intermediate cuttings, which make the stand more spatial and permeable. In line with such an explanation, a steep increase in recreational value does not happen to spontaneous successional stands.

Note also that the results were consistent when we evaluated a rather low number of environments; six forests in the rating task and eight forests in DCE. The consistency of the preferences towards a broader set of environments may be different.

\subsection{Limitation of Our Research}

One of the limitations of the present research is the fact that not all variants of the reclamation practices (replantation vs. unmanaged succession) in all age variants exist yet and thus were not available for photographs. Therefore, we were not able to estimate the effects of all forest types (tree species) and age independently and up to the age of common commercial timber forest, i.e., 80 years. 
Another potential limitation of our research stems from the fact that we used visual representations of respective environments in the form of photographs and hypothetical behavior instead of actual recreation behavior on-site. This might have resulted in higher or lower estimates of recreation values of reclaimed forests. Other studies should validate the relatively high recreation values of older succession and replanted coniferous forests.

Furthermore, in the DCE we have not observed a significant effect of the access time to the locality, which is not fully consistent with the random utility model and its applications in the context of travel behavior $[45,49]$. One possible explanation for such an observation is that access to a recreation locality was not perceived as a cost but a part of the recreational walk in the forest, as suggested by previous findings [50]. While this was not the focus of the present study, the non-significant effect of travel time in the recreational context deserves to be investigated further.

\subsection{Succession in the Context of Other Ecosystem Services}

Positive recreational values of forests growing spontaneously on open-cast coal mine spoil heaps are also worth considering in the context of other ecosystem services. To compare succession and replanted forests in this framework, it is possible to use biophysical research that has been carried out in post-mining localities in the Sokolov region over the past twenty years.

For example, in the field of regulating ecosystem services, previous research, e.g., [39], shows that succession forests achieve much lower carbon storage (half that of spruce stands and one third compared to alder stands of the same age). However, completely different results are offered from the biodiversity perspective. It has been shown that forests growing spontaneously provide refuge for a higher number of plant species compared to planted forests [51].

When comparing the ecosystem services provided, we must take into account local environmental conditions and the usually slower development of the soil and vegetation cover of spontaneously reclaimed sites [52]. At the same time, if the objective is multifunctional land use of post-mining sites, it is important that the diversity of habitat conditions of successional forests also support the restoration of the natural ecosystems as sites for native flora and fauna. From this perspective, successful restoration of forests on post-mining sites should be realized within a framework that accepts variation in objectives and expected results for individual sites and their habitat conditions.

\section{Conclusions}

This study aimed at exploring differences in recreation value between unmanaged successional forests and replanted forests on open-cast mine spoil heaps. Based on the analysis of data from an online survey we found that the recreation value of spontaneously growing successional forests is comparable with the recreation value of replanted forests, and that the recreation value, similarly to the recreation value of other types of forests, significantly increases with the age of the forest. Our results imply that succession may be used as a viable and low-cost reclamation practice of spoil heaps emerging as a by-product of open-cast coal mining, also with respect to their value for recreation.

Supplementary Materials: The following are available online at https:/ /www.mdpi.com/1999-490 7/12/2/160/s1 in xlsx format, Table S1. Data set for ordinal logit model, Table S2. Data set for the multinomial logit model.

Author Contributions: Conceptualization, M.B.K.; methodology, M.B.K. and J.M.; investigation, M.B.K. and J.M.; data curation, M.B.K., V.M., and J.M.; writing-original draft preparation, M.B.K., V.M., P.P., and J.M.; writing-review and editing, M.B.K., V.M., and J.M.; visualization, V.M. and J.M.; supervision, M.B.K.; project administration, J.M.; funding acquisition, J.M. All authors have read and agreed to the published version of the manuscript.

Funding: This research received funding from the Ministry of Agriculture of the Czech Republic (grant QK1710241—Optimization of management of forest restoration on sites affected by surface mining). 
Institutional Review Board Statement: Ethical consent was not required for this non-medical study at the time of implementation.

Informed Consent Statement: Informed consent was obtained from all subjects involved in the study.

Data Availability Statement: The data presented in this study are available in Supplementary Materials.

Conflicts of Interest: The authors declare no conflict of interest. The funders had no role in the design of the study, in the collection, analyses, or interpretation of data, in the writing of the manuscript, or in the decision to publish the results.

\section{Appendix A}

Table A1. Direct measure evaluation; $2 \times 2$ factorial between-subject design $(N=869)$.

\begin{tabular}{|c|c|c|c|c|}
\hline & \multirow{3}{*}{$2 \times 2$ factorial design } & & \multicolumn{2}{|c|}{ 2. Manipulated Factor } \\
\hline & & & \multicolumn{2}{|c|}{ Information on the origin of the forest } \\
\hline & & & Displayed & Not displayed \\
\hline \multirow{2}{*}{ 1. Manipulated Factor } & \multirow{2}{*}{ Successional forest } & At age 15 years & $226(26 \%)$ & $224(26 \%)$ \\
\hline & & At age 35 years & $190(22 \%)$ & $229(26 \%)$ \\
\hline
\end{tabular}

Note: In the factorial design table, we report number of respondents (and their relative frequencies in brackets) assigned for each of the four experimental conditions. 
Spr75
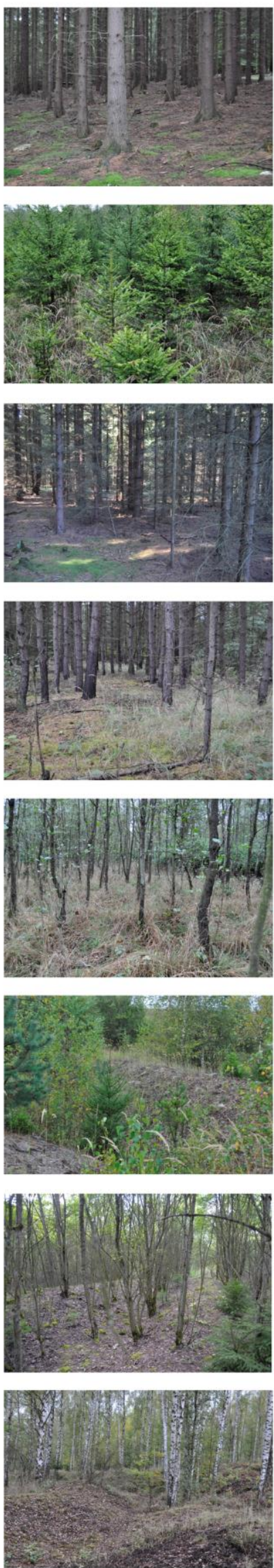

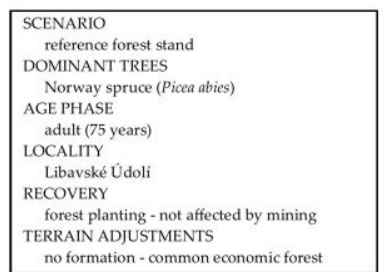

\begin{tabular}{|l|}
\hline SCENARIO \\
forest reclamation \\
DOMINANT TREES \\
Norway spruce (Picea abies) \\
AGE PHASE \\
early (10-15 years) \\
LOCALITY \\
Podkrušnohorská heap \\
RECOVEY \\
forest planting \\
TERRAIN ADJUSTMENTS \\
leveling and soil compaction \\
\hline
\end{tabular}

\begin{tabular}{|l|}
\hline SCENARIO \\
forest reclamation \\
DOMINANT TREES \\
Norway spruce (Picea abies) \\
AGE PHASE \\
advanced (40-55 years) \\
LOCALITY \\
Antonin heap \\
RECOVERY \\
forest planting \\
TERRAIN ADJSTMENTS \\
leveling and soil compaction \\
\hline
\end{tabular}

\begin{tabular}{|l|}
\hline SCENARIO \\
forest reclamation \\
DOMINANT TREES \\
Scots pine (Pinus sylvestris) \\
AGE PHASE \\
adult (40-55 years) \\
LOCALITY \\
Antonin heap \\
RECOVERY \\
forest planting \\
TERRAIN ADJUSTMENTS \\
leveling and soil compaction \\
\hline
\end{tabular}

\begin{tabular}{|l|}
\hline SCENARIO \\
forest reclamation \\
DOMINANT TREES \\
Black alder (Alnus glutinosa) \\
AGE PHASE \\
middle (20-30 years) \\
LOCALITY \\
Podkrušnohorská heap \\
RECOVER \\
forest planting \\
TERRAIN ADJUSTMENTS \\
leveling and soil compaction \\
\hline
\end{tabular}

\begin{tabular}{|l|}
\hline SCENARIO \\
spontaneous succession \\
DOMINANT TREES \\
White birch, Scots pine, Norway spruce \\
AGE PHASE \\
early (10-15 years) \\
LOCALITY \\
Podkrušnohorská heap \\
RECOVERY \\
natural renewal \\
TERRAIN ADJUSTMENTS \\
pouring into waves and no leveling \\
\hline
\end{tabular}

\begin{tabular}{|l|}
\hline SCENARIO \\
spontaneous succession \\
DOMINANT TREES \\
Goat willow (Salix caprea) \\
AGE PHASE \\
middle (20-30 years) \\
LOCALITY \\
Podkrušnohorská heap \\
RECOVERY \\
natural renewal \\
TERRAIN ADJUSTMENTS \\
pouring into waves and no leveling \\
\hline
\end{tabular}

\begin{tabular}{|l|}
\hline SCENARIO \\
spontaneous succession \\
DOMINANT TREES \\
White birch (Betula pendula) \\
AGE PHASE \\
advanced (40-55 years) \\
LOCALITY \\
Smolnická heap \\
RECOVERY \\
natural renewal \\
TERRAIN ADJUSTMENTS \\
pouring into waves and no leveling \\
\hline
\end{tabular}
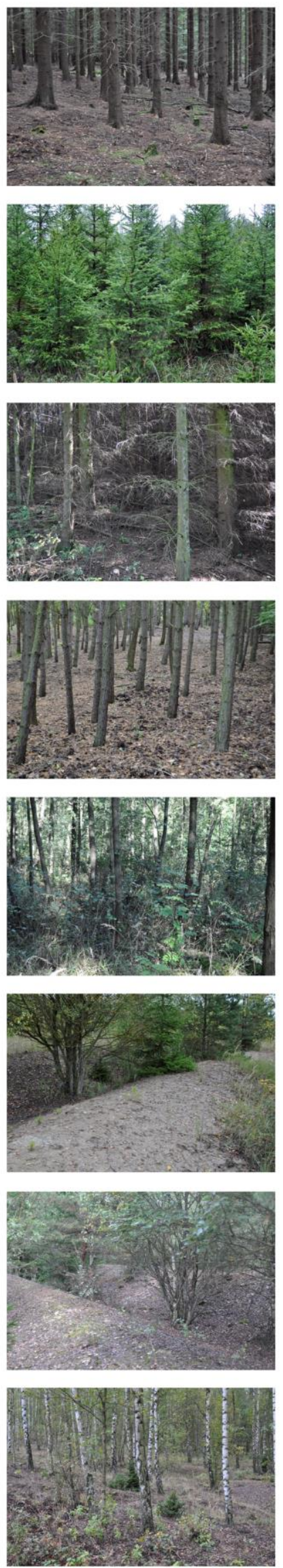

Figure A1. Visual representations and forest management characteristics of the evaluated forests. 


\section{References}

1. Bufka, A.; Rosecký, D.; Bednář, P. Uhlí, Koks a Brikety v České Republice v Roce 2007; Ministry of Industry and Trade: Prague, Czech, 2009.

2. Czech Mining Authority Přehled dobývacích Prostorů v České Republice. Available online: http://www.cbusbs.cz/cs/ component/k2/item/107 (accessed on 29 November 2020).

3. Routa, M. Ekonomická Náročnost Sanace a Rekultivace v Oblasti Sokolovska. Ph.D. Thesis, Czech University of Life Sciences, Prague, Czech Republic, 2009. Available online: https:/ / www.fld.czu.cz/dl/47003 (accessed on 17 January 2021).

4. Ministry of Finance of the Czech Republic Informace na Žádost Podle Zákona č. 106/1999 Sb., o Svobodném Přístupu k Informacím, č.j. MF-18169/2018/10/741 IK. 2018. Available online: https:/ / www.mfcr.cz/assets/cs/media/Informace-zadost106_2018-07-27_Info-106-99-MF-18169-2018-10-741-IK.pdf (accessed on 17 January 2021).

5. Karjalainen, E. The Visual Preferences for Forest Regeneration and Field Afforestation-Four Case Studies in Finland. Ph.D. Thesis, Finnish Forest Research Institute and Faculty of Biosciences of University of Helsinki, Helsinki, Finland, 2006. [CrossRef]

6. Gundersen, V.S.; Frivold, L.H. Public preferences for forest structures: A review of quantitative surveys from Finland, Norway and Sweden. Urban For. Urban Green. 2008, 7, 241-258. [CrossRef]

7. Pukkala, T.; Kellomäki, S.; Mustonen, E. Prediction of the amenity of a tree stand. Scand. J. For. Res. 1988, 3, 533-544. [CrossRef]

8. Silvennoinen, H.; Alho, J.; Kolehmainen, O.; Pukkala, T. Prediction models of landscape preferences at the forest stand level. Landsc. Urban Plan. 2001, 56, 11-20. [CrossRef]

9. Silvennoinen, H.; Pukkala, T.; Tahvanainen, L. Effect of Cuttings on the Scenic Beauty of a Tree Stand. Scand. J. For. Res. 2002, 17, 263-273. [CrossRef]

10. Tyrväinen, L.; Silvennoinen, H.; Kolehmainen, O. Ecological and aesthetic values in urban forest management. Urban For. Urban Green. 2003, 1, 135-149. [CrossRef]

11. Upton, V.; Dhubháin, Á.N.; Bullock, C. Preferences and values for afforestation: The effects of location and respondent understanding on forest attributes in a labelled choice experiment. For. Policy Econ. 2012, 23, 17-27. [CrossRef]

12. Nielsen, A.B.; Olsen, S.B.; Lundhede, T. An economic valuation of the recreational benefits associated with nature-based forest management practices. Landsc. Urban Plan. 2007, 80, 63-71. [CrossRef]

13. Valasiuk, S.; Czajkowski, M.; Giergiczny, M.; Żylicz, T.; Veisten, K.; Landa Mata, I.; Halse, A.H.; Elbakidze, M.; Angelstam, P. Is forest landscape restoration socially desirable? A discrete choice experiment applied to the Scandinavian transboundary Fulufjället National Park Area. Restor. Ecol. 2018, 26, 370-380. [CrossRef]

14. Kaplan, R.; Herbert, E.J. Cultural and sub-cultural comparisons in preferences for natural settings. Landsc. Urban Plan. 1987, 14, 281-293. [CrossRef]

15. Zheng, B.; Zhang, Y.; Chen, J. Preference to home landscape: Wildness or neatness? Landsc. Urban Plan. 2011, 99, 1-8. [CrossRef]

16. Purcell, A.T.; Lamb, R.J.; Peron, E.M.; Falchero, S. Preference or preferences for landscape? J. Environ. Psychol. 1994, 14, 195-209. [CrossRef]

17. Hartig, T.; Staats, H. The need for psychological restoration as a determinant of environmental preferences. J. Environ. Psychol. 2006, 26, 215-226. [CrossRef]

18. Kohlová, M.B.; Melichar, J. Environmental preferences for forest growth in post-mining landscape. J. Landsc. Manag. 2017, 8, 14-19.

19. Tahvanainen, L.; Tyrväinen, L.; Ihalainen, M.; Vuorela, N.; Kolehmainen, O. Forest management and public perceptions-Visual versus verbal information. Landsc. Urban Plan. 2001, 53, 53-70. [CrossRef]

20. Shuttleworth, S. The use of photographs as an environmental presentation medium in landscape studies. J. Environ. Manag. 1980, $11,61-76$.

21. Stamps, A.E. Use of photographs to simulate environments: A meta-analysis. Percept. Mot. Skills 1990, 71, 907-913. [CrossRef]

22. Palmer, J.F.; Hoffman, R.E. Rating reliability and representation validity in scenic landscape assessments. Landsc. Urban Plan. 2001, 54, 149-161. [CrossRef]

23. Zube, E.H.; Pitt, D.G.; Anderson, T.W. Perception and Measurement of Scenic Resources in the Southern Connecticut River Valley. Landsc. Res. 1974, 1, 10-11. [CrossRef]

24. Kroh, D.P.; Gimblett, R.H. Comparing live experience with pictures in articulating landscape preference. Landsc. Res. 1992, 17, 58-69. [CrossRef]

25. Svobodova, K.; Sklenicka, P.; Molnarova, K.; Salek, M. Visual preferences for physical attributes of mining and post-mining landscapes with respect to the sociodemographic characteristics of respondents. Ecol. Eng. 2012, 43, 34-44. [CrossRef]

26. Filova, L.; Vojar, J.; Svobodova, K.; Sklenicka, P. The effect of landscape type and landscape elements on public visual preferences: Ways to use knowledge in the context of landscape planning. J. Environ. Plan. Manag. 2015, 58, 2037-2055. [CrossRef]

27. Simonic, T. Preference and perceived naturalness in visual perception of naturalistic landscapes. Zb. Biotech. Fak. Univ. Ljublj. Kmet. 2003, 81, 369-389.

28. Harris, V.; Kendal, D.; Hahs, A.K.; Threlfall, C.G. Green space context and vegetation complexity shape people's preferences for urban public parks and residential gardens. Landsc. Res. 2018, 43, 150-162. [CrossRef]

29. Daniel, T.C.; Meitner, M.M. Representational validity of landscape visualizations: The effects of graphical realism on perceived scenic beauty of forest vistas. J. Environ. Psychol. 2001, 21, 61-72. [CrossRef] 
30. Champ, P.A. Collecting Nonmarket Valuation Data. In A Primer on Nonmarket Valuation. The Economics of Non-Market Goods and Resources; Champ, P.A., Boyle, K.J., Brown, T.C., Eds.; Springer Netherlands: Dordrecht, The Netherlands, 2017; pp. 55-82. [CrossRef]

31. Bateman, I.J.; Carson, R.T.; Day, B.; Hanemann, W.M. Economic Valuation with Stated Preference Techniques: A Manual; Edward Elgar: Cheltenham, UK, 2004; ISBN 1843768526.

32. Freeman, A.M.I. The Measurement of Environmental and Resource Values: Theory and Methods; Resources for the Future: Washington, DC, USA, 2003; ISBN 9781891853623.

33. Christie, M.; Hanley, N.; Hynes, S. Valuing enhancements to forest recreation using choice experiment and contingent behaviour methods. J. For. Econ. 2007, 13, 75-102. [CrossRef]

34. Hensher, D.A.; Rose, J.M.; Greene, W.H. Applied Choice Analysis: A Primer; Cambridge University Press: Cambridge, MA, USA, 2005.

35. Holmes, T.P.; Adamowicz, W.L.; Carlsson, F. Choice Experiments. In A Primer on Nonmarket Valuation. The Economics of Non-Market Goods and Resources; Champ, P., Boyle, K., Brown, T., Eds.; Springer Netherlands: Dordrecht, The Netherlands, 2017 ; pp. 133-186. [CrossRef]

36. Czajkowski, M.; Buszko-Briggs, M.; Hanley, N. Valuing changes in forest biodiversity. Ecol. Econ. 2009, 68, 2910-2917. [CrossRef]

37. Czajkowski, M.; Giergiczny, M.; Greene, W.H. Learning and Fatigue Effects Revisited: Investigating the Effects of Accounting for Unobservable Preference and Scale Heterogeneity. Land Econ. 2014, 90, 324-351. [CrossRef]

38. Bartczak, A.; Lindhjem, H.; Navrud, S.; Zandersen, M.; Żylicz, T. Valuing forest recreation on the national level in a transition economy: The case of Poland. For. Policy Econ. 2008, 10, 467-472. [CrossRef]

39. Frouz, J.; Pižl, V.; Cienciala, E.; Kalčík, J. Carbon storage in post-mining forest soil, the role of tree biomass and soil bioturbation. Biogeochemistry 2009, 94, 111-121. [CrossRef]

40. Frouz, J.; Mudrák, O.; Reitschmiedová, E.; Walmsley, A.; Vachová, P.; Šimáčková, H.; Albrechtová, J.; Moradi, J.; Kučera, J. Rough wave-like heaped overburden promotes establishment of woody vegetation while leveling promotes grasses during unassisted post mining site development. J. Environ. Manag. 2018, 205, 50-58. [CrossRef]

41. de Val, G.F.; Atauri, J.A.; de Lucio, J.V. Relationship between landscape visual attributes and spatial pattern indices: A test study in Mediterranean-climate landscapes. Landsc. Urban Plan. 2006, 77, 393-407. [CrossRef]

42. Tveit, M.; Ode, Å.; Fry, G. Key concepts in a framework for analysing visual landscape character. Landsc. Res. 2006, 31, 229-255. [CrossRef]

43. Melichar, J. The economic valuation of the change in forest quality in the Jizerske hory mountains: A contingent behavior model. J. Landsc. Manag. 2014, 5, 6.

44. Louviere, J.; Hensher, D.A.; Swait, J.D. Stated Choice Methods; Cambridge University Press: Cambridge, MA, USA, 2000; ISBN 0511011733 virtual.

45. Ben-Akiva, M.E.; Lerman, S.R. Discrete Choice Analysis: Theory and Application to Travel Demand; MIT Press: Cambridge, MA, USA, 1985.

46. Han, K.T. Responses to six major terrestrial biomes in terms of scenic beauty, preference, and restorativeness. Environ. Behav. 2007, 39, 529-556. [CrossRef]

47. Sklenicka, P.; Molnarova, K. Visual perception of habitats adopted for post-mining landscape rehabilitation. Environ. Manag. 2010, 46, 424-435. [CrossRef]

48. Kohlová, M.B.; Máca, V.; Melichar, J. Post-mining nature. When visual attractiveness is not enough. In International Conference of Environmental Psychology. Protecting People and Planet through Social and Behavioural Science (ICEP 2019); University of Plymouth: Plymouth, UK, 2019.

49. Jara-Díaz, S.R. Allocation and Valuation of Travel-Time Savings. In Handbook of Transport Modelling; Hensher, D.A., Button, K.J., Eds.; Elsevier Science Ltd.: Oxford, UK, 2000; pp. 303-319.

50. Mokhtarian, P.L.; Salomon, I.; Redmond, L.S. Understanding the demand for travel: It's not purely "derived". Innovation 2001, 14, 355-380. [CrossRef]

51. Mudrák, O.; Frouz, J.; Velichová, V. Understory vegetation in reclaimed and unreclaimed post-mining forest stands. Ecol. Eng. 2010, 36, 783-790. [CrossRef]

52. Frouz, J. (Ed.) Soil Biota and Ecosystem Development in Post Mining Sites; CRC Press: Boca Raton, FL, USA, 2013; ISBN 9781466599338. 